\title{
Differential Responses of Two Broccoli (Brassica oleracea L. var Italica) Cultivars to Salinity and Nutritional Quality Improvement
}

\author{
Chokri Zaghdoud, ${ }^{1}$ Carlos Alcaraz-López, ${ }^{2}$ César Mota-Cadenas, ${ }^{2}$ \\ María del Carmen Martínez-Ballesta, ${ }^{2}$ Diego A. Moreno, ${ }^{3}$ \\ Ali Ferchichi, ${ }^{1}$ and Micaela Carvajal ${ }^{2}$ \\ ${ }^{1}$ Laboratoire d'Aridoculture et Cultures Oasiennes, Institut des Régions Arides, Route de Djerba Km 22.5, Médenine 4119, Tunisia \\ ${ }^{2}$ Department of Plant Nutrition, Centro de Edafología y Biología Aplicada del Segura (CEBAS-CSIC), \\ Campus Universitario de Espinardo, Ap. de Correos 164, 30100 Murcia, Spain \\ ${ }^{3}$ Department of Food Science and Technology, Centro de Edafología y Biología Aplicada del Segura (CEBAS-CSIC), \\ Campus Universitario de Espinardo, Ap. de Correos 164, 30100 Murcia, Spain
}

Correspondence should be addressed to María del Carmen Martínez-Ballesta, mballesta@cebas.csic.es

Received 2 May 2012; Accepted 30 May 2012

Academic Editors: C. Cilas, C. de Souza, and R. Sarkar

Copyright ( 12012 Chokri Zaghdoud et al. This is an open access article distributed under the Creative Commons Attribution License, which permits unrestricted use, distribution, and reproduction in any medium, provided the original work is properly cited.

The comparative responses of two broccoli cultivars (Brassica oleracea var. Italica, cv. Parthenon and cv. Naxos) to a 15-d exposure to different $\mathrm{NaCl}$ levels were investigated. Salinity led to increased concentrations of $\mathrm{Na}^{+}$and $\mathrm{Cl}^{-}$ions in both cultivars, a disruption of the endogenous minerals levels in the shoots and roots—-that varied with the cultivar and salt concentration-and decreases in the osmotic potential $\left(\Psi_{\pi}\right)$, root hydraulic conductance $\left(L_{0}\right)$, and stomatal conductance $\left(G_{s}\right)$. The reduced biomass of Naxos at moderate $\mathrm{NaCl}$ indicates its greater sensitivity to salinity, compared with Parthenon. Parthenon accumulated more soluble sugars, for osmotic adjustment, whereas Naxos accumulated proline, which gave the two cultivars differing nutritional characteristics. The total glucosinolates (GSLs) content was not affected by salinity in Parthenon while it decreased significantly in Naxos as a consequence of the decrease in the indole GSL. However, Naxos accumulated more aliphatic GSLs under salt stress than Parthenon, which confers on this cultivar a greater nutritional value when cultivated under salinity. These results suggest that, at distinct salinity levels, each broccoli cultivar adopts a specific strategy, indicating the crucial role of the genetic background on the organoleptic and nutritional properties that each cultivar acquires.

\section{Introduction}

Salt accumulation in irrigated soils is one of the main factors that diminish crop productivity, since most of the plant species cultivated are not halophytic. Therefore, it is important to understand how plants respond and adapt to salinity. Salt tolerance in plants is a complex phenomenon, which depends on a number of interrelated factors based on morphological, biochemical, and physiological processes $[1,2]$.

The first response of plants to salt stress is osmotic adjustment. Salinity-stressed plants tend to accumulate compatible solutes in their cytoplasm, to balance ions in the vacuole [3]. These compatible solutes are low-molecular-mass compounds that do not interfere with normal biochemical reactions. They include proline (Pro), glycine betaine [4], sugars [5], and polyols [6]. Generally, compatible solutes protect plants from stress through different processes, including contributions to the cellular water economy, detoxification of reactive oxygen species, protection of membrane integrity, and stabilisation of enzymes/proteins [7].

High external levels of $\mathrm{NaCl}$ reduce root hydraulic conductance $\left(L_{0}\right)$ [8] because of a toxic effect that has a negative influence on the concentration or functionality of 
aquaporins [9-11]. The decrease of the root $L_{0}$ by salinity has been shown to lower the water flow from roots to shoots, even in osmotically adjusted plants $[12,13]$. This decrease in water flow may lower the leaf water content, resulting in stomatal closure in order to maintain the water status [13, 14]. Salinity-provoked reduction of stomatal conductance $\left(G_{s}\right)$ has been reported in plants of Phaseolus [15], rice [16], amaranth [17], and mangrove [18]. These authors attributed the decreases of $G_{s}$ and, in turn, of photosynthetic carbon assimilation, to the toxic effects of $\mathrm{Na}^{+}$and $\mathrm{Cl}^{-}$.

Glucosinolates (GSLs) are sulphur-containing compounds characteristic of the Brassicaceae and are recognised as having human health-promoting effects related to sulphate assimilation [19]. It has been shown that the glucosinolate content can be altered by environmental factors, such as temperature and photoperiod [20], season [21] or sulphur fertilisation [22]. Under salt stress, GSLs have been observed to increase [23], suggesting that under low water potential they could be involved in osmotic adjustment and might be an adaptive component of salt tolerance [24]. However, more information is needed regarding the effect of external stress on GSL accumulation in plants. Phenolic compounds, to which are attributed health-promoting effects due to their antioxidant properties [19], have been found in high amounts in broccoli (Brassica oleracea var. Italica) [25]. Salt stress has been shown to induce disturbances in the secondary metabolic pathways, leading to increased accumulation of phenolic compounds [26].

Broccoli is a recognised health-promoting vegetable and one of the most important vegetables produced in the Southeast of Spain, under semiarid climatic conditions, and it is consumed frequently by people from both Western and Eastern cultures [27]. Broccoli plants are moderately salt tolerant [28], and the mechanism of tolerance has been studied by our group for many years.

Thus, the aim of this work was to compare the behaviours of two broccoli cultivars (Parthenon and Naxos) in relation to their osmotic adjustment to salt stress and variations of health-promoting compounds under salinity. For that, plant growth, water relations, proline, and soluble sugars as well as mineral content, glucosinolates, and phenolic compounds were determined. The effects of the saline treatments and cultivar factor were analysed individually.

\section{Materials and Methods}

2.1. Plant Growth and Experimental Design. Two broccoli cultivars (Brassica oleracea var. italica, cvs. Parthenon and Naxos) were used for the experiments. While Parthenon has been studied widely, Naxos is introduced here as a new cultivar highly tolerant of abiotic stress. The two studied varieties differ in their culture cycle and are the main varieties in the regional market.

Seeds of broccoli (cvs. Parthenon and Naxos, kindly provided by SAKATA Seeds Iberica) were prehydrated with deionised water and aerated continuously for $12 \mathrm{~h}$. The seeds were then placed on trays with vermiculite as substrate before being placed in an incubator chamber at $28^{\circ} \mathrm{C}$, in darkness. After $2 \mathrm{~d}$, they were transferred to a controlled environment chamber with a $16 \mathrm{~h}$ light and $8 \mathrm{~h}$ dark cycle, with air temperatures of 25 and $20^{\circ} \mathrm{C}$, respectively. The relative humidity $(\mathrm{RH})$ was $60 \%$ (light period) and $80 \%$ (dark), and the photosynthetically active radiation (PAR) was $400 \mu \mathrm{mol} \mathrm{m} \mathrm{m}^{-2} \mathrm{~s}^{-1}$, provided by a combination of fluorescent tubes (TLD36W/83, Philips, Hamburg, Germany and F36W/GRO, Sylvania, Danvers, MA, USA) and metal-halide lamps (HQI, T 400W; Osram, München, Germany).

After $3 \mathrm{~d}$, the seedlings were placed in $15-\mathrm{L}$ containers (10 plants per container) filled with continuously aerated Hoagland nutrient solution: $\mathrm{KNO}_{3}(3.0 \mathrm{mM})$, $\mathrm{Ca}\left(\mathrm{NO}_{3}\right)_{2}(2.0 \mathrm{mM}), \mathrm{KH}_{2} \mathrm{PO}_{4}(0.5 \mathrm{mM}), \mathrm{MgSO}_{4}(0.5 \mathrm{mM})$, $\mathrm{H}_{3} \mathrm{BO}_{3}(25.0 \mu \mathrm{M}), \mathrm{MnSO}_{4}(2.0 \mu \mathrm{M}), \mathrm{ZnSO}_{4}(2.0 \mu \mathrm{M})$, $\mathrm{CuSO}_{4}(0.5 \mu \mathrm{M}),\left(\mathrm{NH}_{4}\right)_{6} \mathrm{Mo}_{7} \mathrm{O}_{24}(0.5 \mu \mathrm{M})$, and Fe-EDTA $(20.0 \mu \mathrm{M})$. The solution was completely replaced every week. After 2 weeks of growth (when the plants were $17 \mathrm{~d}$ old), the plants were separated ( 5 per container with the same Hoagland nutrient solution) and treated with $0,30,60$, or $90 \mathrm{mM} \mathrm{NaCl}$. A Split-Plot design, with two factors $(\mathrm{NaCl}$ treatment, cultivar) and five replications, was used, to analyse each physiological variable. The salt treatments were applied to the nutrient solution by addition of $30 \mathrm{mM} \mathrm{NaCl}$ every hour until the final $\mathrm{NaCl}$ concentrations of $0,30,60$, and $90 \mathrm{mM}$ were reached, in order to avoid osmotic shock. After $15 \mathrm{~d}$ of $\mathrm{NaCl}$ treatment, the plants were harvested for analysis. Five replications of each treatment were used for the determinations.

2.2. Growth Parameters and Relative Water Content (RWC). The total dry biomass was obtained after drying the fresh organs at $70^{\circ} \mathrm{C}$ until constant weight. The leaf area was measured every day after applying $\mathrm{NaCl}$, using the method described by Paul et al. [29]. The relative water content (RWC) was calculated as \% of water.

2.3. Analysis of Anions and Cations. The cation concentrations were determined in samples (ca $100 \mathrm{mg}$ DW) of the oven-dried plant materials. The samples were digested, after $\mathrm{HNO}_{3}-\mathrm{H}_{2} \mathrm{O}_{2}(2: 1)$ addition, in a microwave oven (CEM Mars Xpress, NC, USA). The concentrations of calcium $\left(\mathrm{Ca}^{2+}\right)$, potassium $\left(\mathrm{K}^{+}\right)$, magnesium $\left(\mathrm{Mg}^{2+}\right)$, and sodium $\left(\mathrm{Na}^{+}\right)$were analysed by ICP spectrometry (Iris Intrepid II, Thermo Electron Corporation, Franklin, USA).

The concentrations of chloride $\left(\mathrm{Cl}^{-}\right)$, nitrate $\left(\mathrm{NO}_{3}{ }^{-}\right)$, sulphate $\left(\mathrm{SO}_{4}{ }^{2-}\right)$, and phosphate $\left(\mathrm{PO}_{4}{ }^{3-}\right)$ were measured in a Dionex-D-100 ion chromatograph with an IonPac AS124$4 \mathrm{~mm}(10-32)$ column and an AG $14(4 \times 50 \mathrm{~mm})$ guard column. The flow rate was adjusted to $1 \mathrm{~mL} \mathrm{~min}^{-1}$, with an eluent of $0.5 \mathrm{mM} \mathrm{Na}_{2} \mathrm{CO}_{3}$ and $0.5 \mathrm{mM} \mathrm{NaHCO}_{3}$.

2.4. Soluble Sugars and Proline Determination. The content of soluble sugars (SSs) in the leaf sap was determined according to Loewus [30]. The cell sap was collected from the most recent fully expanded leaves of the broccoli plants, which were frozen at $-80^{\circ} \mathrm{C}$ and centrifuged at $5000 \times \mathrm{g}$ for $5 \mathrm{~min}$, at $4^{\circ} \mathrm{C}$. The sap was then filtered through sep-pak C18 cartridges. An aliquot of the filtered sap was reacted with 
anthrone reagent (containing $5 \mathrm{mM}$ anthrone and $70 \%(\mathrm{v} / \mathrm{v})$ $\mathrm{H}_{2} \mathrm{SO}_{4}$ ) by heating in a water bath at $100^{\circ} \mathrm{C}$ for $10 \mathrm{~min}$; and the absorbance of the coloured complex was measured at 650 nm using a spectrophotometer (Beckman DU-40).

The free Pro contents were determined according to the method of Bates et al. [31], with some modifications. The leaf sap used for SS determination was filtered again, through a $0.45 \mu \mathrm{m}$ pore-size filter. The reaction was initiated by combining $200 \mu \mathrm{L}$ of the sample, $250 \mu \mathrm{L}$ of ninhydrin reagent (containing $140 \mathrm{mM}$ ninhydrin, $60 \%(\mathrm{v} / \mathrm{v})$ glacial acetic acid and $6 \mathrm{M}$ phosphoric acid), $250 \mu \mathrm{L}$ of $99 \%(\mathrm{v} / \mathrm{v})$ glacial acetic acid, and $400 \mu \mathrm{L}$ of distilled water; this mixture was incubated for $1 \mathrm{~h}$ at $100^{\circ} \mathrm{C}$. The absorbance of the chromophore in toluene was measured at $515 \mathrm{~nm}$ in a spectrophotometer, using toluene as blank. A standard curve was prepared for each assay, using different dilutions of a $50 \mu \mathrm{g} / \mathrm{mL}$ Pro stock solution.

2.5. Leaf Osmotic Potential. The most-recent fully-expanded leaves were put into Eppendorf tubes and frozen rapidly with liquid nitrogen. They were subsequently thawed and centrifuged to extract the cell sap.

The osmotic potential $\left(\Psi_{\pi}\right)$ of the leaf sap was calculated from the sap osmolarity, measured using an automatic, freezing-point-depression osmometer (Digital Osmometer, Roebling, Berlin), by the van't Hoff equation (Nobel 1991) [32]:

$$
\Psi_{\pi}=n R T,
$$

where $n$ is the osmotic concentration (mOsmol), $R$ is the gas constant $\left(0.083 \mathrm{~L} \mathrm{~atm} \mathrm{~K} \mathrm{~K}^{-1} \mathrm{~mol}^{-1}\right)$, and $T$ is the ambient temperature $(\mathrm{K})$.

\subsection{Stomatal Conductance and Root Hydraulic Conductance.} The adaxial stomatal conductance $\left(G_{s}\right)$ was measured every day for $15 \mathrm{~d}$ after applying $\mathrm{NaCl}$, using a portable photosynthesis system (model LCA-4, ADC BioScientific Ltd., Hoddesdon, UK) and a PLC- $4 \mathrm{~N}$ leaf chamber $\left(11.35 \mathrm{~cm}^{2}\right)$, configured to an open system. The most-recent fullyexpanded leaves were chosen for the analysis. The measurements were made in the middle of the photoperiod in order to obtain the highest values.

The root hydraulic conductance $\left(L_{0}\right)$ was measured by natural exudation. Three days before the measurements, plants of the different treatments were separated in $1 \mathrm{~L}$ containers, individually. For $L_{0}$ measurements, the aerial parts of the plants were removed, leaving the base of the stem, which was sealed with silicone grease into a tapered plastic tube. The sap accumulated was collected in Eppendorf tubes. The roots and the Eppendorf tubes were weighed in a precision balance. The sap flow $\left(J_{v}\right)$ was expressed in $\mathrm{mg} g$ (root fresh weight) ${ }^{-1} \mathrm{~h}^{-1}$. The osmotic pressure difference $\left(\Delta \Psi_{\pi}\right)$ between the $J_{v}$ and the corresponding nutrient solution was calculated according to their osmolarity values. The $L_{0}$ was determined by the following equation:

$$
L_{0}=\frac{J_{v}}{\Delta \Psi_{\pi}} \operatorname{mgg}(\text { root fresh weight })^{-1} \mathrm{~h}^{-1} \mathrm{MPa}^{-1} \text {. }
$$

The measurements were made in the middle of the photoperiod, 15 days after applying $\mathrm{NaCl}$.

2.7. Glucosinolate and Phenolic Compounds Determination. Glucosinolates and phenolic compounds were analysed according to the procedure described by Domínguez-Perles et al. [33] being expressed as mg per $g$ of fresh weight and $\mathrm{mg}$ per $100 \mathrm{~g}$ of fresh weight, respectively.

2.8. Statistics. The statistical analyses were performed using SPSS Release 18 for Windows. Significant differences between treatments for each cultivar were determined according to Tukey's test at $P \leq 0.05$. Significant differences between cultivars were determined according to the Student's $t$-test at $P \leq 0.05, P \leq 0.01$, and $P \leq 0.001$.

\section{Results}

The shoot and root dry weights (DWs) were decreased by salinity for both cultivars (Table 1). However, the decreases were more pronounced in plants of $\mathrm{cv}$. Naxos than for Parthenon $(P \leq 0.001)$ at $60 \mathrm{mM} \mathrm{NaCl}$. Thus, at $60 \mathrm{mM}$ $\mathrm{NaCl}$, significant reductions were observed only for Naxos; compared with the control plants, shoot DW was reduced by about $17 \%$ and $43 \%$ for Parthenon and Naxos, respectively, and root DW by $21 \%$ and $34 \%$, respectively. Similarly, at $90 \mathrm{mM} \mathrm{NaCl}$, reductions in the shoot DW of $44 \%$ and $54 \%$ were observed for Parthenon and Naxos, respectively. The relative water content (RWC) of the shoots and roots of $\mathrm{cv}$. Parthenon did not change with salinity, but a slight increase at moderate $\mathrm{NaCl}$ concentration was observed for Naxos.

In control plants, the leaf area was greater for $\mathrm{cv}$. Parthenon than for Naxos $(P \leq 0.05)$ (Table 1). However, whereas the decrease in the shoot DW was greater for Naxos, the leaf area reduction was more pronounced in cv. Parthenon. At $90 \mathrm{mM} \mathrm{NaCl}$, the leaf area reduction compared to the control was $48 \%$ and $38 \%$, for Parthenon and Naxos, respectively (Table 1).

The results of the analyses of mineral nutrients in the shoots and roots are shown in Table 2. In control plants, the $\mathrm{K}^{+}$concentration was much higher than those of other ions. In both cultivars, the $\mathrm{Na}^{+}$and $\mathrm{Cl}^{-}$levels increased with increasing $\mathrm{NaCl}$ concentration and these ions accumulated mostly in the shoots. In the shoots, both cultivars showed a progressive decrease of the $\mathrm{K}^{+}$level with increasing salt stress. Comparing the cultivars, significant differences were observed at $30 \mathrm{mM} \mathrm{NaCl}(P \leq 0.001)$, with a greater reduction in $\mathrm{K}^{+}$for $\mathrm{cv}$. Naxos. The root $\mathrm{K}^{+}$concentration decreased with increasing salinity, but only in Naxos were there significant differences among the $\mathrm{NaCl}$ treatments. Similar results occurred for $\mathrm{Ca}^{2+}$ in the shoots of both cultivars. Also, the $\mathrm{Mg}^{2+}$ concentrations were decreased in the shoots by salinity, for both cultivars, with higher values being maintained by cv. Naxos $(P \leq 0.001)$ at 30 and $60 \mathrm{mM}$ $\mathrm{NaCl}$, in relation to $\mathrm{cv}$. Parthenon. The $\mathrm{NO}_{3}{ }^{-}$levels were also decreased by salt stress but, in contrast to $\mathrm{K}^{+}$, significant differences among the external $\mathrm{NaCl}$ concentrations were recorded only in the roots of Parthenon. The $\mathrm{SO}_{4}{ }^{2-}$ level 
TABLE 1: Dry weight (DW), relative water content (RWC), and leaf area of Parthenon and Naxos cultivars after different salt treatments for 15 days. Values are means \pm standard errors $(n=5)$. Means followed by different letters are significantly different according to Tukey's test at $P<0.05$. The significance of the difference between the two cultivars is given according to the Student's $t$-test, with ${ }^{*} P<0.05$, ${ }^{* *} P<0.01$, $* * * P<0.001 ;$ n.s: non-significant.

\begin{tabular}{|c|c|c|c|c|c|c|c|}
\hline \multirow{2}{*}{ Cultivar } & \multirow{2}{*}{$\mathrm{NaCl}(\mathrm{mM})$} & \multicolumn{2}{|c|}{ DW $\left(\right.$ g plant $\left.^{-1}\right)$} & \multirow{2}{*}{$\begin{array}{c}\text { Root: shoot } \\
\text { ratio }\end{array}$} & \multicolumn{2}{|c|}{ RWC (\%) } & \multirow{2}{*}{$\begin{array}{l}\text { Third leaf area } \\
(\mathrm{cm})\end{array}$} \\
\hline & & Shoot & Root & & Shoot & Root & \\
\hline \multirow{4}{*}{ Parthenon } & 0 & $3.87 \pm 0.23 \mathrm{a}$ & $0.55 \pm 0.03 \mathrm{a}$ & $0.14 \mathrm{a}$ & $90.19 \pm 0.36 \mathrm{a}$ & $91.88 \pm 0.24 \mathrm{a}$ & $161.02 \pm 8.01 \mathrm{a}$ \\
\hline & 30 & $3.70 \pm 0.32 \mathrm{a}$ & $0.54 \pm 0.03 \mathrm{a}$ & $0.15 \mathrm{a}$ & $90.99 \pm 0.12 \mathrm{a}$ & $92.05 \pm 0.13 \mathrm{a}$ & $137.27 \pm 11.14 \mathrm{ab}$ \\
\hline & 60 & $3.19 \pm 0.12 \mathrm{a}$ & $0.43 \pm 0.03 \mathrm{ab}$ & $0.14 \mathrm{a}$ & $90.90 \pm 0.08 \mathrm{a}$ & $92.14 \pm 0.16 \mathrm{a}$ & $113.03 \pm 2.60 \mathrm{bc}$ \\
\hline & 90 & $2.17 \pm 0.20 b$ & $0.31 \pm 0.02 \mathrm{~b}$ & $0.15 \mathrm{a}$ & $90.68 \pm 0.14 \mathrm{a}$ & $91.66 \pm 0.17 \mathrm{a}$ & $83.84 \pm 5.25 c$ \\
\hline \multirow{4}{*}{ Naxos } & 0 & $3.07 \pm 0.19 a$ & $0.49 \pm 0.05 \mathrm{a}$ & $0.16 \mathrm{a}$ & $90.40 \pm 0.18 \mathrm{a}$ & $91.49 \pm 0.27 \mathrm{ab}$ & $137.50 \pm 2.43 \mathrm{a}$ \\
\hline & 30 & $2.78 \pm 0.14 \mathrm{a}$ & $0.47 \pm 0.02 \mathrm{a}$ & $0.17 \mathrm{a}$ & $91.43 \pm 0.10 \mathrm{ab}$ & $92.06 \pm 0.34 b$ & $134.74 \pm 8.12 \mathrm{a}$ \\
\hline & 60 & $1.74 \pm 0.14 \mathrm{~b}$ & $0.32 \pm 0.02 \mathrm{~b}$ & $0.19 \mathrm{a}$ & $92.21 \pm 0.17 \mathrm{~b}$ & $91.88 \pm 0.25 \mathrm{ab}$ & $105.09 \pm 4.16 \mathrm{~b}$ \\
\hline & 90 & $1.41 \pm 0.14 b$ & $0.26 \pm 0.03 \mathrm{~b}$ & $0.19 \mathrm{a}$ & $91.48 \pm 0.10 \mathrm{ab}$ & $90.97 \pm 0.38 \mathrm{a}$ & $85.17 \pm 5.54 \mathrm{~b}$ \\
\hline \multirow{4}{*}{$\begin{array}{l}\text { Significance between } \\
\text { the two cultivars }\end{array}$} & 0 & * & n.s. & n.s. & n.s. & n.s. & * \\
\hline & 30 & * & n.s. & n.s. & * & n.s. & n.s. \\
\hline & 60 & $* * *$ & $*$ & $*$ & n.s. & n.s. & n.s. \\
\hline & 90 & $*$ & n.s. & n.s. & $* *$ & n.s. & n.s. \\
\hline
\end{tabular}

increased only in the shoots of Parthenon at $30 \mathrm{mM} \mathrm{NaCl}$ and decreased in the roots of this cultivar with all salt treatments. However, for Naxos, $\mathrm{SO}_{4}{ }^{2-}$ decreased only at $90 \mathrm{mM} \mathrm{NaCl}$, in both shoots and roots. In contrast to Parthenon, the $\mathrm{PO}_{4}{ }^{3-}$ levels in the roots of Naxos were unaffected by salinity.

Plants of cv. Parthenon exhibited a higher SS concentration in their leaf sap than those of Naxos, under all salinity treatments $(P \leq 0.001$ at 30 and $60 \mathrm{mM} \mathrm{NaCl}$ and $P \leq 0.01$ at $90 \mathrm{mM} \mathrm{NaCl}$ ) (Figure 1(a)). At $60 \mathrm{mM} \mathrm{NaCl}$, the SSs were increased by $45 \%$ and $33 \%$ in the leaf sap of Parthenon and Naxos, respectively, compared to control plants; the increases reached 1.7-fold and 2-fold, respectively, at $90 \mathrm{mM} \mathrm{NaCl}$. By contrast, in cv. Parthenon, an increased Pro concentration occurred only at the highest $\mathrm{NaCl}$ treatment $(90 \mathrm{mM})$, whereas in cv. Naxos higher Pro accumulation was observed as salinity increased (Figure 1(b)). Leaf sap Pro levels were increased about 11 -fold and 17-fold in $90 \mathrm{mM} \mathrm{NaCl}$-treated Parthenon and Naxos plants, respectively, compared with control plants. Thus, leaf sap Pro accumulation differed significantly $(P \leq 0.001)$ between cultivars for salt-treated plants but not under nonstressing conditions.

In Parthenon, the leaf sap $\Psi_{\pi}$ was decreased only at the highest salt concentrations (60 and $90 \mathrm{mM} \mathrm{NaCl}$ ), with respect to the control plants, whereas, in Naxos, it was reduced gradually by increasing salinity, the decrease reaching $42 \%$, compared to the control value, at $90 \mathrm{mM}$ $\mathrm{NaCl}$ (Figure 2(a)). However, at high salinity, the $\Psi_{\pi}$ of the root xylem sap was decreased slightly in Naxos, compared to Parthenon $(P \leq 0.001)$ (Figure 2(b)).

During the 15 days of treatment, salinity provoked gradual decreases in the $G_{s}$ and $L_{0}$ of the Parthenon and Naxos plants (Figure 3). However, the intensity of this decrease varied with the cultivar and the largest reduction in $L_{0}$ at $90 \mathrm{mM} \mathrm{NaCl}$ was recorded in Parthenon. Our results show also a positive correlation between $L_{0}$ and $G_{s}$, in both cultivars.
The content of total GSL was expressed as the sum of the indole (glucobrassicin, neoglucobrassicin, 4-OHglucobrassicin and 4-MeO-glucobrassicin) and aliphatic (glucoiberin, glucoraphanin, and glucoerucin) GSL analysed (Figure 4(a)). In control plants, the total GSL concentration was higher for Naxos than for Parthenon $(P \leq 0.001)$, a result of the higher neoglucobrassicin level in Naxos. The total GSL concentration in Naxos plants was decreased significantly by $\mathrm{NaCl}$ addition to the nutrient solution. This decrease reached $46.2 \%$ at $90 \mathrm{mM} \mathrm{NaCl}$, compared to control plants and was the result of a greater decrease in the total indole GSL concentrations (Figure 4(b)), mainly glucobrassicin and neoglucobrassicin. In Parthenon, the total GSL concentration did not vary with the external $\mathrm{NaCl}$ concentration. In both cultivars, salinity induced an increase in the total aliphatic GSL (Figure 4(c)). At 60 and $90 \mathrm{mM}$ $\mathrm{NaCl}$, this increase was significant $(P \leq 0.001)$ for both cultivars and was related particularly to the increase in glucoerucin concentration. At $90 \mathrm{mM} \mathrm{NaCl}$, the increase in total aliphatic GSL reached 4.18-fold and 3.34-fold in Naxos and Parthenon, respectively, compared to the control values (Figure 4(c)).

In this study, some natural antioxidants in broccoli are expressed as the content of phenolic compounds (chlorogenic, flavonoids, and sinapic acid derivatives). In the leaves of Naxos, there were no significant differences for any of the phenolic compounds analysed between control plants and salt-treated plants (Figure 5). However, in Parthenon, the levels of sinapic acid derivatives were enhanced significantly by increasing salinity, in comparison with $\mathrm{cv}$. Naxos $(P \leq$ 0.001) (Figure 5(c)).

\section{Discussion and Conclusions}

Salt stress induced a decrease in the shoot and root DWs of both broccoli cvs., which resulted in a constant root/shoot 


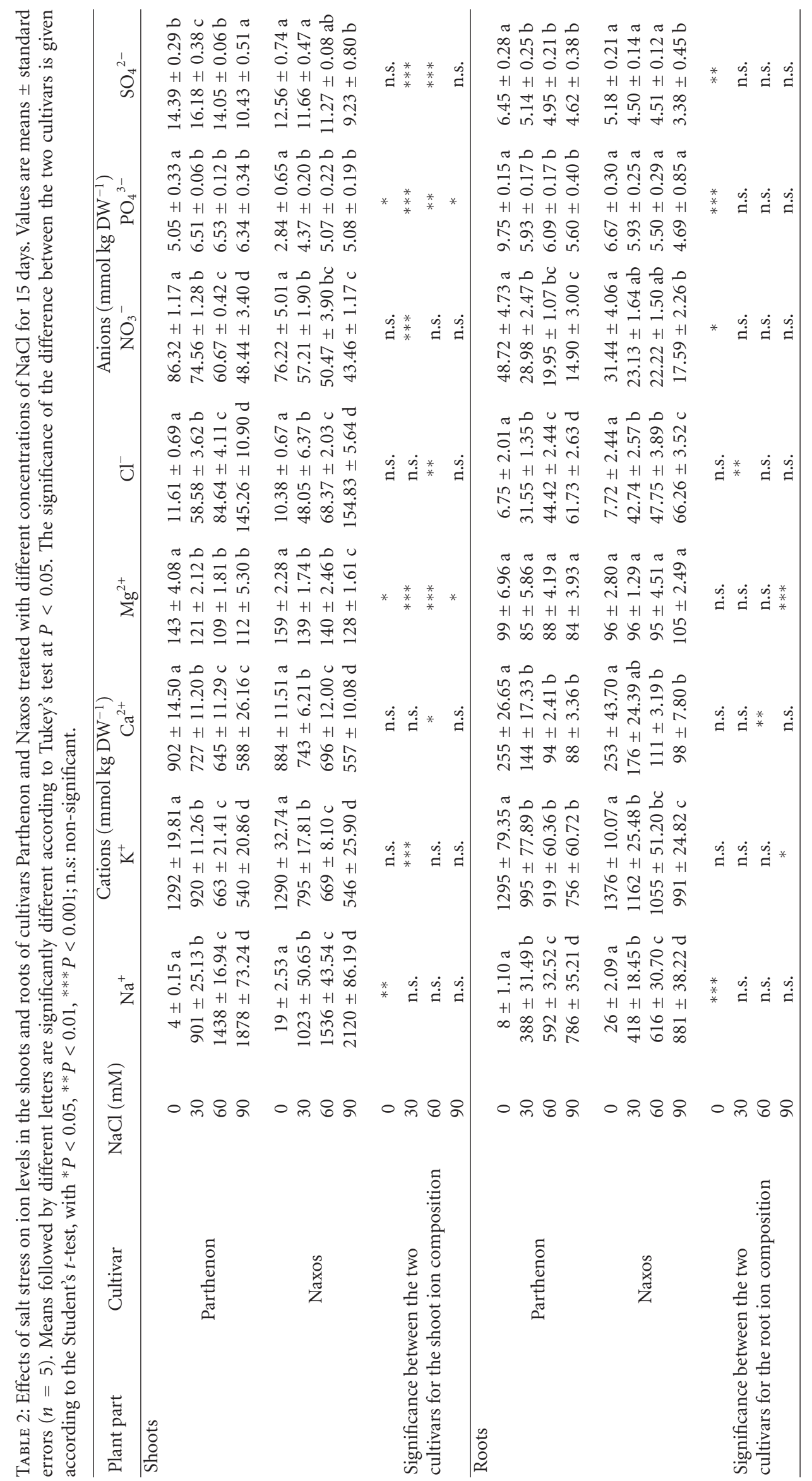




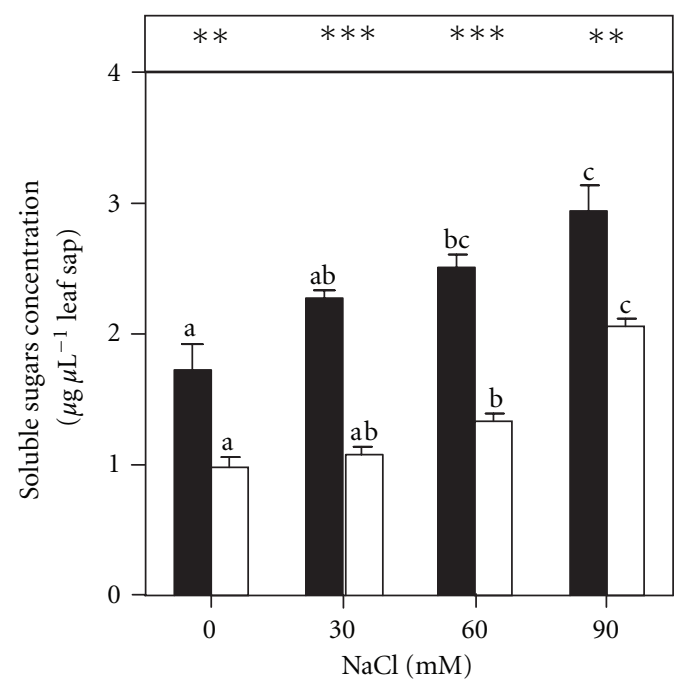

(a)

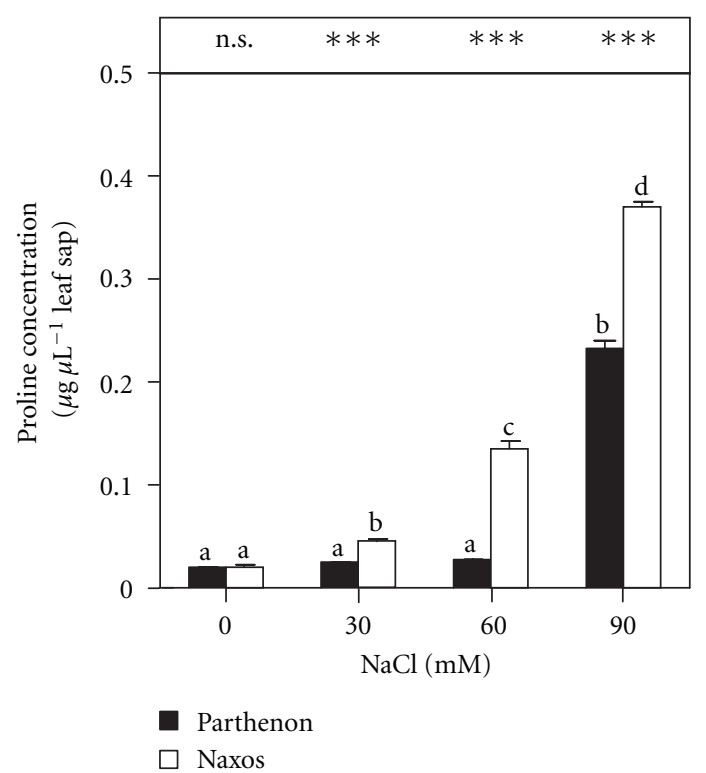

(b)

FIGURE 1: Leaf sap soluble sugars (a) and proline (b) concentrations of broccoli plants grown under saline conditions (0, 30, 60, or $90 \mathrm{mM}$ $\mathrm{NaCl})$ for 15 days $(n=5 \pm \mathrm{SE})$. Column values with the same letters are not significantly different $(P<0.05$ for soluble sugars and $P<$ 0.01 for proline, Tukey's test). The significance of the difference between the two cultivars was given according to the Student's $t$-test, with ${ }^{*} P<0.05,{ }^{* *} P<0.01,{ }^{* * *} P<0.001 ;$ n.s: nonsignificant.

ratio and a reduction in the leaf area. However, these decreases in DW were more pronounced in cultivar Naxos than in Parthenon and the shoot biomass reduction for Naxos at moderate $\mathrm{NaCl}$ concentration indicates a greater sensitivity of this cultivar to salinity. In fact, shoot biomass has been shown as a trait for salt tolerance indication [34]. A similar decrease in the growth of broccoli plants under saline conditions was observed by López-Berenguer et al. [23, 28]. Leaf area decrease has been considered as the major cause of growth reduction, due to the decline in the photosynthetic area [35]. However, the greater decrease in the shoot DW of Naxos in relation to Parthenon, despite a greater leaf area reduction in Parthenon, could be explained by the reduction of the stem biomass for cv. Naxos.

Salinity induced a considerable accumulation of salt ions $\left(\mathrm{Cl}^{-}\right.$and $\left.\mathrm{Na}^{+}\right)$in the plants, mainly $\mathrm{Na}^{+}$, whose level was higher in the shoots than in the roots. However, in the shoots, both cultivars maintained or increased their RWC under the salt treatments. Similar results were reported for different Brassica genotypes [36]. This stability of the RWC, despite the internal accumulation of salt ions, could reflect an inclusive response of broccoli plants to salinity, with salt being accumulated in the cells of the aerial organs, mainly in the vacuoles [37]. The vacuolar accumulation of salt ions under salinity leads to osmotic adjustment [38]. Thus, to achieve osmotic balance with the vacuole, the cytoplasm accumulates low-molecular-mass compounds, termed compatible solutes, because they do not interfere with normal biochemical reactions [3]; rather, they replace water in biochemical reactions. In accordance with this, there was a significant increase in the SS concentration in
Parthenon plants even at the lowest external salt concentration $(30 \mathrm{mM} \mathrm{NaCl})$, whereas in Naxos a significant increase in these osmolytes was recorded only at $90 \mathrm{mM} \mathrm{NaCl}$. Sugars act as osmotica and/or protect specific macromolecules and contribute to the stabilisation of membrane structures [39]. They also may protect cells during desiccation, by forming glasses [40]. By contrast, under saline conditions, higher accumulation of Pro was recorded in cv. Naxos. Besides osmotic adjustment, other roles have been proposed for Pro in osmotically stressed plant tissues: protection of plasma membrane integrity [41], a sink of energy or reducing power [42], a source of carbon and nitrogen [43], or a hydroxyl radical scavenger [44]. The differences in SS and Pro accumulation between cultivars Parthenon and Naxos under saline stress reflect the distinct strategies adopted by each cultivar to achieve osmotic adjustment. Zhu [45] reported that plants have to decrease their internal water potential in order to avoid the dehydration caused by salinity; this implies a decrease of the $\Psi_{\pi}$, to maintain turgor and achieve osmotic adjustment. Anyway, the greater magnitude of the SS concentrations relative to Pro suggests the necessity for osmotic adjustment in Parthenon, which was not reflected in the leaf $\Psi_{\pi}$; thus, accumulation of other osmolytes cannot be ruled out.

The $L_{0}$ is known to decrease under high salinity [46, 47]. In the present study, salt stress led to a progressive reduction in the $L_{0}$ values of both broccoli cultivars. The decrease in $L_{0}$ can be attributed to the toxic effects of $\mathrm{Na}^{+}$and $\mathrm{Cl}^{-}$, which reduce the passage of water through the plasma membrane. However, in other species, the $L_{0}$ decrease was evaluated in terms of the osmotic effects of $\mathrm{Na}^{+}$and $\mathrm{Cl}^{-}[48,49]$. The 


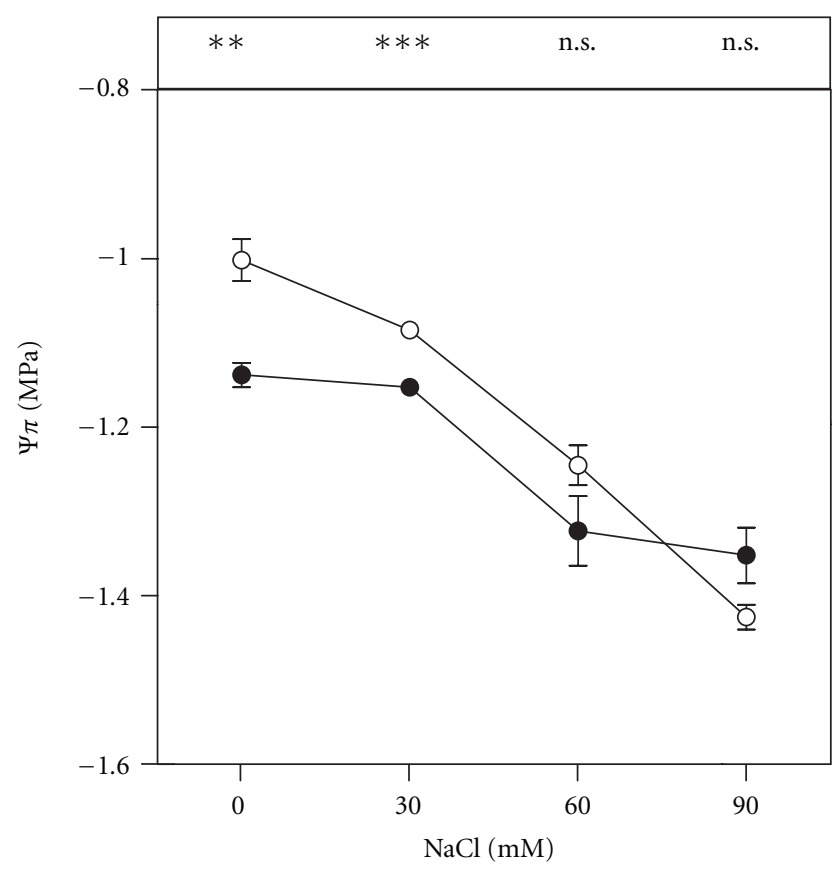

(a)

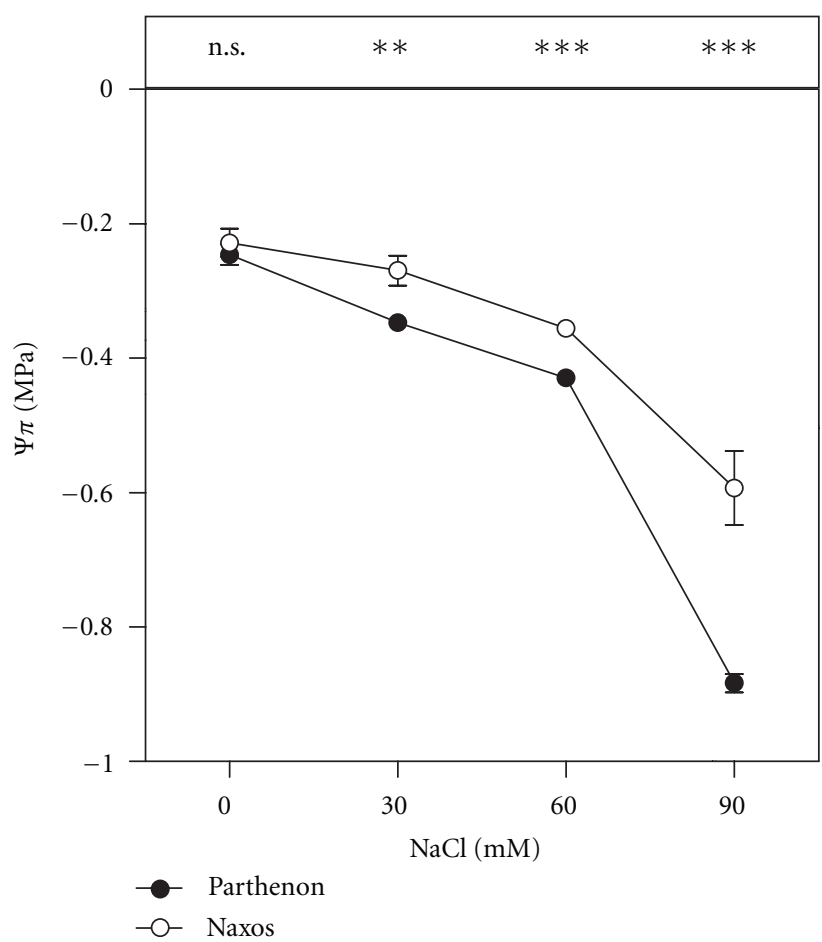

(b)

Figure 2: Osmotic potential $\left(\Psi_{\pi}\right)$ of leaf sap (a) and root xylem sap (b) of broccoli plants grown under saline conditions $(0,30,60$, or 90 mM $\mathrm{NaCl})$ for 15 days $(n=5 \pm \mathrm{SE})$. The significance of the difference between the two cultivars was given according to the Student's $t$-test, with ${ }^{*} P<0.05,{ }^{* *} P<0.01,{ }^{* * *} P<0.001 ;$ n.s: nonsignificant.

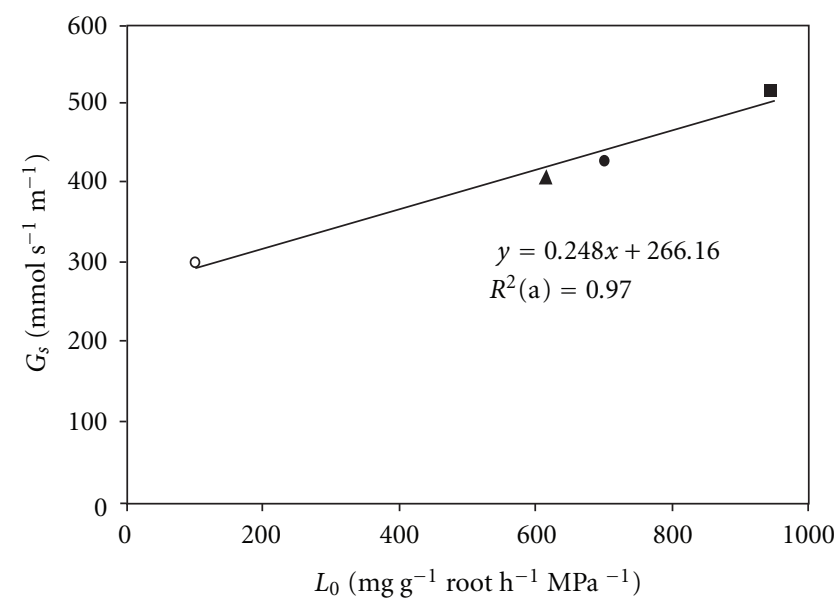

(a)

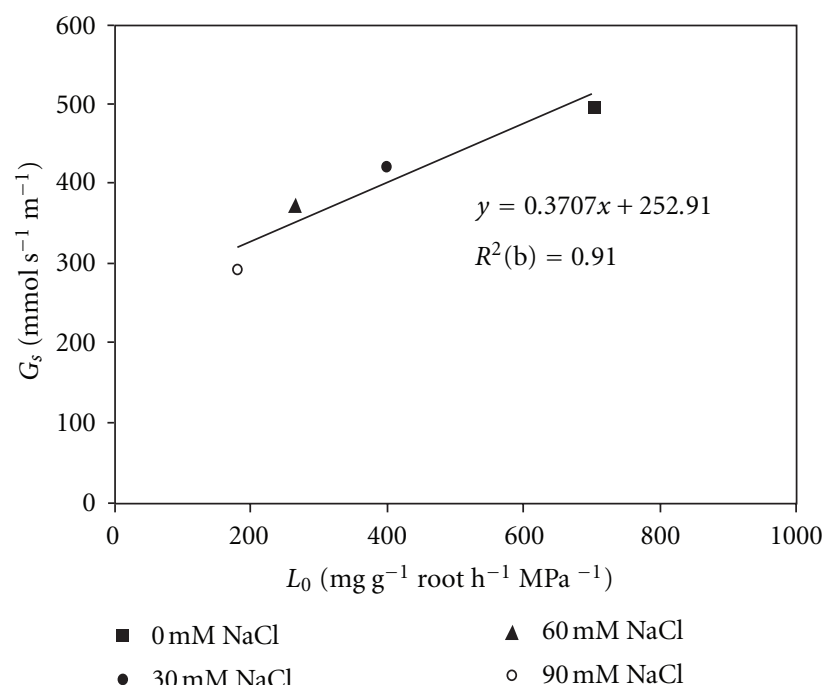

(b)

FIGURE 3: Correlation between stomatal conductance $\left(G_{s}\right)$ and root hydraulic conductance $\left(L_{0}\right)$ in cultivars Parthenon (a) and Naxos (b) grown under saline conditions $(0,30,60$, or $90 \mathrm{mM} \mathrm{NaCl})$ for 15 days $(n=4 \pm \mathrm{SE})$.

decrease in $L_{0}$ in Parthenon and Naxos could also have been the result of a toxic effect of the high salt ion concentrations on root aquaporin functionality, since in previous work we showed a lack of correlation between $L_{0}$ and the amount of PIP1 and PIP2 proteins under salt stress [50]. In fact, in
Naxos, a larger increase in the amount of PIP2 proteins under the saline conditions imposed, compared with Parthenon, may have resulted in the rapid uptake of water into root cells, to dilute the $\mathrm{NaCl}$ that also entered the cells [51], therefore lowering the requirement for osmotic adjustment. 


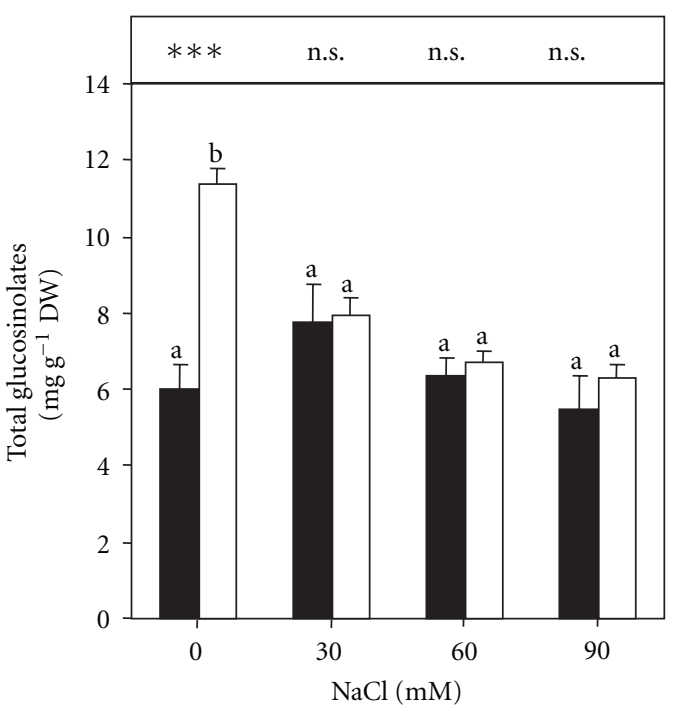

(a)

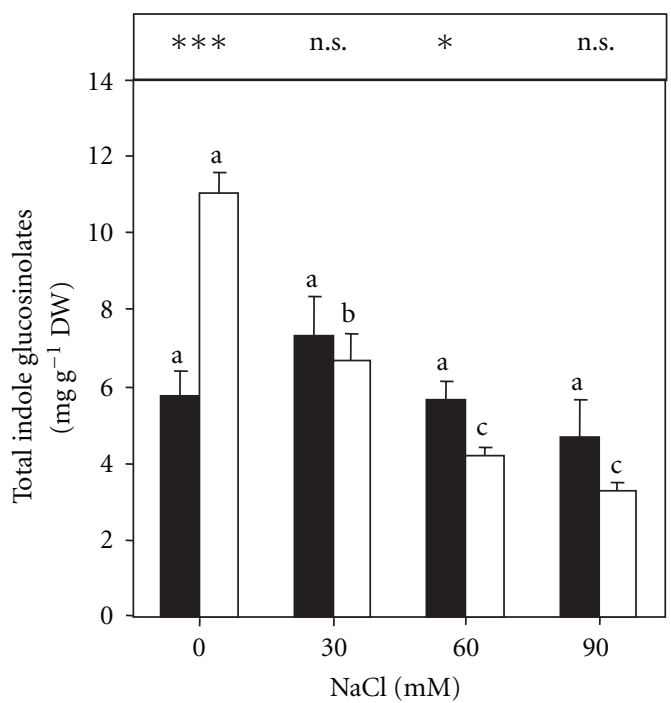

(b)

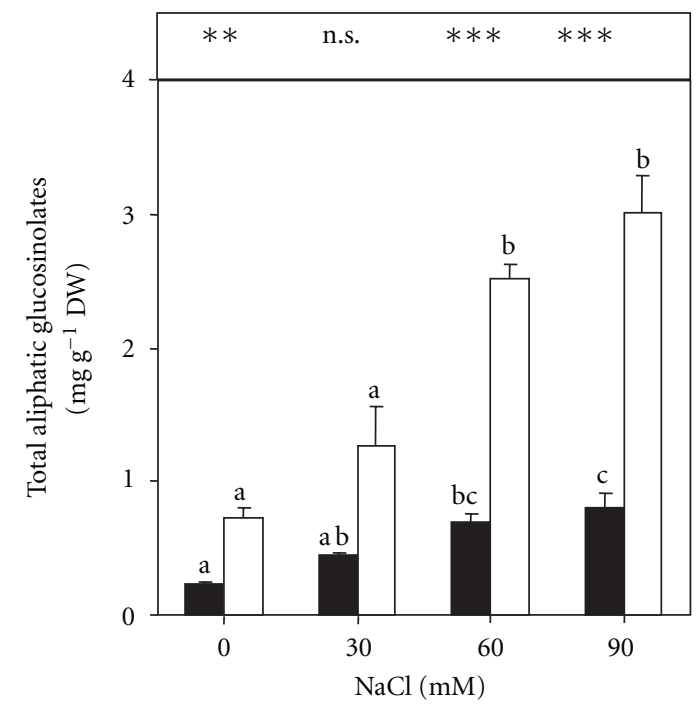

Parthenon

$\square$ Naxos

(c)

FIGURE 4: The concentrations of total glucosinolates (a), total indole glucosinolates (b), and total aliphatic glucosinolates (c) in the shoots of broccoli plants grown under saline conditions $(0,30,60$, or $90 \mathrm{mM} \mathrm{NaCl})$ for 15 days $(n=5 \pm \mathrm{SE})$. Column values with the same letters are not significantly different $(P<0.05$, Tukey's test). The significance of the difference between the two cultivars was given according to the Student's $t$-test, with ${ }^{*} P<0.05,{ }^{* *} P<0.01,{ }^{* * *} P<0.001$; n.s: nonsignificant.

In addition, leaf $G_{s}$ decreased in both broccoli cultivars with increasing external salinity, together with reductions in $L_{0}$. Similarly, a strong correlation between $G_{s}$ and $L_{0}$ was shown in tomato plants under salt stress [52]. However, the higher slope value for Naxos could indicate a higher stomatal driving force for water transport through these plants under salinity.

Competition effects between different anions and different cations are known to occur in saline environments and they may be deleterious for plant growth [53]. In this work, the accumulation of $\mathrm{Na}^{+}$in salt-treated broccoli induced significant decreases in the $\mathrm{K}^{+}, \mathrm{NO}_{3}{ }^{-}$, and $\mathrm{Ca}^{2+}$ concentrations in both shoots and roots, in agreement with previous results [54]. However, in cultivar Naxos, comparing the moderate- and high-salinity levels, the reductions of $\mathrm{K}^{+}$in the roots and of $\mathrm{Ca}^{2+}$ and $\mathrm{Mg}^{2+}$ in the shoots differed significantly, whereas this level of significance was not observed in Parthenon, indicating differing degrees of sensitivity to moderate- and high-salinity for these two cultivars. In fact, the correlation between $\mathrm{Na}^{+}$accumulation and shoot biomass reduction at different $\mathrm{NaCl}$ concentrations was higher in cv. Naxos $\left(r^{2}=0.88\right)$ compared to Parthenon 


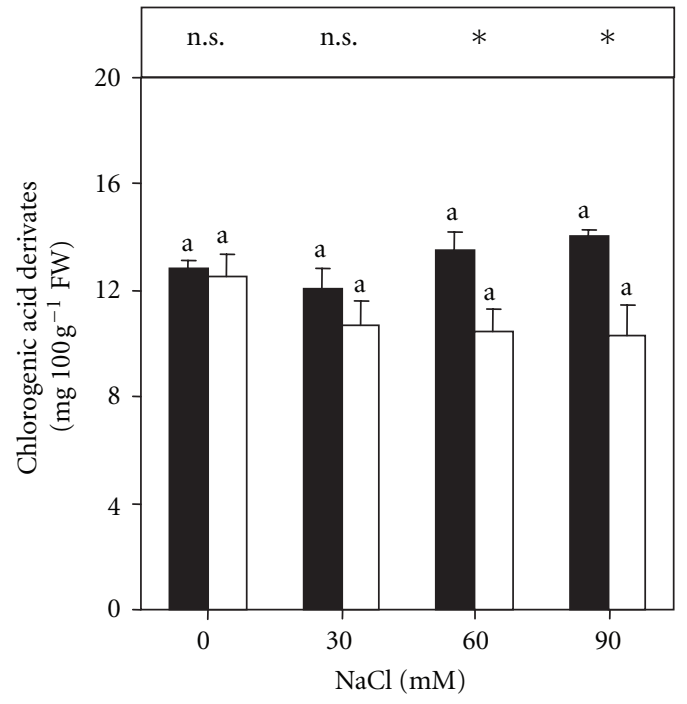

(a)

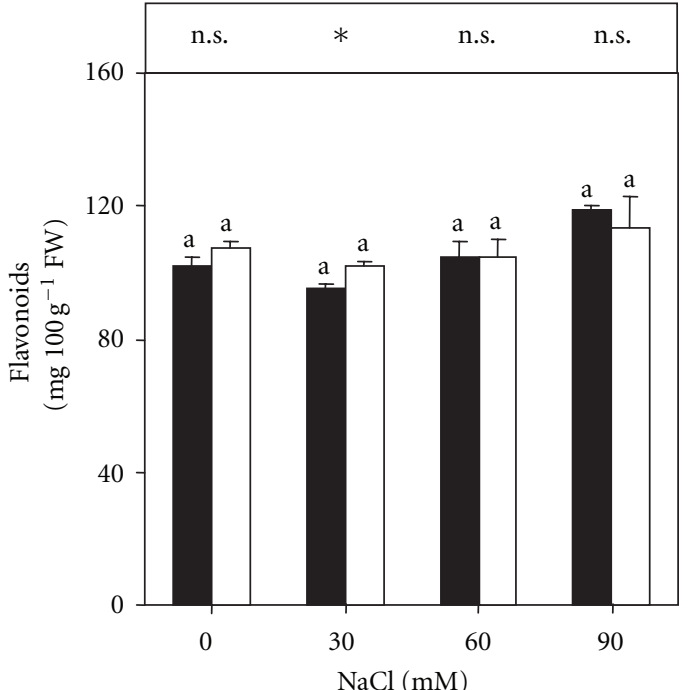

(b)

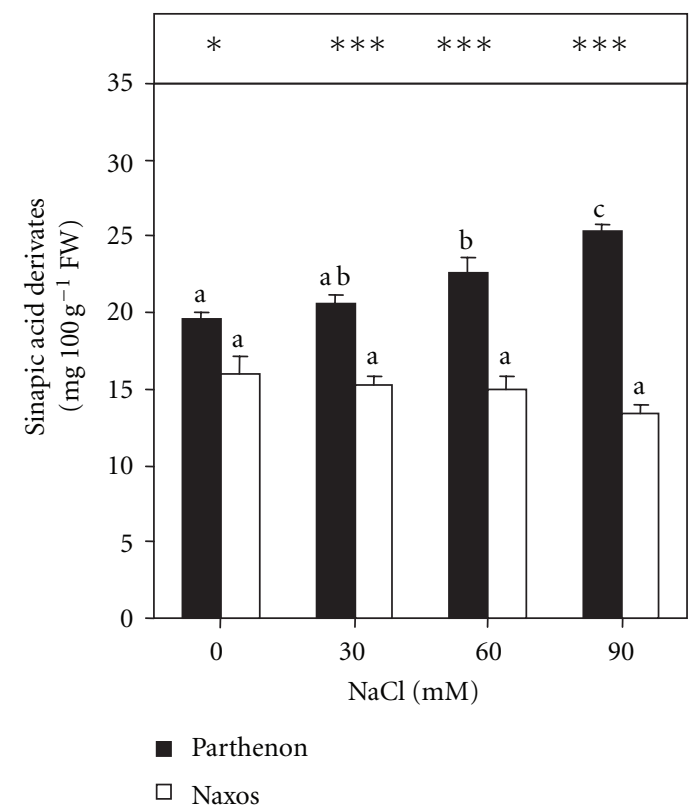

(c)

FIGURE 5: The concentrations of chlorogenic acid derivates (a), flavonoids (b), and sinapic acid derivates (c) in the shoots of broccoli plants grown under saline conditions $(0,30,60$, or $90 \mathrm{mM} \mathrm{NaCl})$ for 15 days $(n=5 \pm \mathrm{SE})$. Column values with the same letters are not significantly different $(P<0.05$, Tukey's test). The significance of the difference between the two cultivars was given according to the Student's $t$-test, with ${ }^{*} P<0.05,{ }^{* *} P<0.01,{ }^{* * *} P<0.001 ;$ n.s: nonsignificant.

$\left(r^{2}=0.77\right)$. The decreases in $\mathrm{NO}_{3}{ }^{-}$concentrations caused by the $\mathrm{NaCl}$ treatments could have been due to inhibition of $\mathrm{NO}_{3}{ }^{-}$uptake by $\mathrm{Cl}^{-}$[55] and low $\mathrm{NO}_{3}{ }^{-}$loading into the root xylem [56].

The GSLs are a category of secondary compounds found mainly in cruciferous plants such as broccoli, cauliflower, and cabbage [57]. Earlier work showed that environmental factors such as light [58], temperature [59], and heavy metals [60] alter the glucosinolate content and composition. At moderate salt stress, a tendency for the total leaf GSL to increase was observed in $\mathrm{cv}$. Parthenon, accompanied by an increase in the $\mathrm{SO}_{4}{ }^{2-}$ concentration in the shoot. These findings agree with the recent results of Keling and Zhujun [61] for Pak choi plants, for which the total GSL concentration was increased at moderate salinity. Also, previous work showed that sulphur assimilation increased the GSL concentration under salinity [23]. The significant decrease $(30 \%$ at $30 \mathrm{mM} \mathrm{NaCl}$, around $40 \%$ at 60 and $90 \mathrm{mM} \mathrm{NaCl}$ ) in the total GSL concentration in cv. Naxos was mainly the consequence of the decrease in the total indole GSL concentration. The differences between the two cultivars of broccoli with respect to their accumulation of $\mathrm{SO}_{4}{ }^{2-}$ and GSL under 
salt exposure suggest that glucosinolate synthesis under salinity depends on the genotype rather than the treatment.

The significant increases of the total aliphatic GSL in Parthenon $(294 \%$ at $60 \mathrm{mM}, 334 \%$ at $90 \mathrm{mM} \mathrm{NaCl}$ ) and Naxos (348\% at $60 \mathrm{mM}, 418 \%$ at $90 \mathrm{mM} \mathrm{NaCl}$ ) were mainly due to the higher accumulation of glucoerucin. Compensation for the decline in indole GSL by increased levels of aliphatic GSL may occur. In fact, the absence of aliphatic GSL in the Arabidopsis thaliana double mutant myb28myb29 led to an increase in the indole GSL [62]. Thus, under salt stress, aliphatic GSLs confer on this cultivar an increased nutritional value. Several products of the hydrolysis of methylsulphinyl aliphatic GSL, such as glucoraphanin (GR) and glucoiberin (GI), in broccoli are considered to reduce the risk of cancers. Sulphoraphane (derived from glucoraphanin) is the most potent, being a naturally occurring inducer of phase 2 enzymes that detoxify carcinogens [63].

Farnham et al. [26] and Scheuner et al. [64] reported that salinity induced an increase in the content of phenolic compounds, although the results referred mainly to the edible parts (florets, inflorescences). Conversely, a number of reports describe how phenolic compounds may decrease as a consequence of long-term plant exposure to $\mathrm{NaCl}$ treatments [65]. Therefore, the way in which abiotic stress factors may influence the content of bioactive phytochemicals of plant material is not absolutely clear. These divergences in the response to stressing factors indicate the importance of the genetic background in the response of broccoli to environmental factors, as in this paper, where the distinct secondary metabolic responses of cultivars Naxos and Parthenon under salt stress were reflected in the levels of both GSL and sinapic acid derivates.

In conclusion, cultivars Parthenon and Naxos employed differing strategies for growth under moderate and high salt stress, indicating the importance of the genetic background as a modifying factor. Naxos seems to be more sensitive, since its biomass reduction due to $\mathrm{NaCl}$ exposure was greater than that of Parthenon. The effect of salinity on endogenous mineral levels varied with the cultivar, organ, and $\mathrm{NaCl}$ concentration. In addition, to achieve osmotic adjustment, Parthenon accumulated more SS whereas Naxos accumulated more Pro, showing that the determinants of the response to salinity in broccoli, regarding osmotic adjustment, are genotype dependent and vary in both the ionic and osmotic phases of salt stress. The effect of salinity on the levels of bioactive compounds differed between the cultivars and conferred on them a greater nutritional value, especially for cv. Naxos due to increases in its aliphatic glucosinolates. Therefore, salt-affected lands could be suitable for broccoli cultivation, in order to obtain increased production of phytochemicals in this crop.

\section{Acknowledgments}

This work was funded by projects of the CICYT (AGL200912720) and the Fundación Seneca-Comunidad Autónoma de la Región de Murcia (08753/PI/08). C. Zaghdoud was supported by The Tunisian Ministry of Higher Education, Scientific Research and Technology. The authors thank Dr. D.
Walker, for the correction of the written English in the paper, and SAKATA IBERICA, for providing the seeds.

\section{References}

[1] H. Greenway and R. Munns, "Mechanisms of salt tolerance in non-halophytes," Annual Reviews of Plant Physiology, vol. 31, pp. 149-190, 1980.

[2] M. Ashraf, "Salt tolerance of cotton: some new advances," Critical Reviews in Plant Sciences, vol. 21, no. 1, pp. 1-30, 2002.

[3] G. Zhifang and W. H. Loescher, "Expression of a celery mannose 6-phosphate reductase in Arabidopsis thaliana enhances salt tolerance and induces biosynthesis of both mannitol and a glucosyl-mannitol dimer," Plant, Cell and Environment, vol. 26, no. 2, pp. 275-283, 2003.

[4] C. Abdul Jaleel, P. Manivannan, A. Kishorekumar, B. Sankar, and R. Panneerselvam, "Calcium chloride effects on salinityinduced oxidative stress, proline metabolism and indole alkaloid accumulation in Catharanthus roseus," Comptes RendusBiologies, vol. 330, no. 9, pp. 674-683, 2007.

[5] I. Kerepesi and G. Galiba, "Osmotic and salt stress-induced alteration in soluble carbohydrate content in wheat seedlings," Crop Science, vol. 40, no. 2, pp. 482-487, 2000.

[6] H. J. Bohnert, D. E. Nelson, and R. G. Jensen, "Adaptations to environmental stresses," Plant Cell, vol. 7, no. 7, pp. 10991111, 1995.

[7] M. Ashraf and M. R. Foolad, "Roles of glycine betaine and proline in improving plant abiotic stress resistance," Environmental and Experimental Botany, vol. 59, no. 2, pp. 206-216, 2007.

[8] L. López-Pérez, N. Fernández-García, E. Olmos, and M. Carvajal, "The phi thickening in roots of broccoli plants: an acclimation mechanism to salinity?" International Journal of Plant Sciences, vol. 168, no. 8, pp. 1141-1149, 2007.

[9] M. D. C. Martínez-Ballesta, V. Martínez, and M. Carvajal, "Regulation of water channel activity in whole roots and in protoplasts from roots of melon plants grown under saline conditions," Australian Journal of Plant Physiology, vol. 27, no. 7, pp. 685-691, 2000.

[10] J. M. Navarro, V. Martínez, and M. Carvajal, "Ammonium, bicarbonate and calcium effects on tomato plants grown under saline conditions," Plant Science, vol. 157, no. 1, pp. 89-96, 2000.

[11] J. M. Navarro, C. Garrido, V. Martínez, and M. Carvajal, "Water relations and xylem transport of nutrients in pepper plants grown under two different salts stress regimes," Plant Growth Regulation, vol. 41, no. 3, pp. 237-245, 2003.

[12] J. W. O'Leary, “The effect of salinity on the permeability of roots to water," Israel Journal of Botany, vol. 18, pp. 1-9, 1969.

[13] J. T. Prisco, "Alguns aspectos da fisiologia do "stress" salino," Revista Brasileira de Botânica, vol. 3, pp. 85-94, 1980.

[14] M. F. Robinson, A. A. Véry, D. Sanders, and T. A. Mansfield, "How can stomata contribute to salt tolerance?" Annals of Botany, vol. 80, no. 4, pp. 387-393, 1997.

[15] J. S. Bayuelo-Jiménez, D. G. Debouck, and J. P. Lynch, "Growth, gas exchange, water relations, and ion composition of Phaseolus species grown under saline conditions," Field Crops Research, vol. 80, no. 3, pp. 207-222, 2003.

[16] M. Djanaguiraman, J. A. Sheeba, A. K. Shanker, D. D. Devi, and U. Bangarusamy, "Rice can acclimate to lethal level of salinity by pretreatment with sublethal level of salinity through osmotic adjustment," Plant and Soil, vol. 284, no. 1-2, pp. 363 373, 2006. 
[17] E. N. Omami and P. S. Hammes, "Interactive effects of salinity and water stress on growth, leaf water relations, and gas exchange in amaranth (Amaranthus spp.)," New Zealand Journal of Crop and Horticultural Science, vol. 34, no. 1, pp. 33-44, 2006.

[18] N. Suárez and E. Medina, "Influence of salinity on $\mathrm{Na}^{+}$and $\mathrm{K}^{+}$accumulation, and gas exchange in Avicennia germinans," Photosynthetica, vol. 44, no. 2, pp. 268-274, 2006.

[19] J. W. Finley, "Proposed criteria for assessing the efficacy of cancer reduction by plant foods enriched in carotenoids, glucosinolates, polyphenols and selenocompounds," Annals of Botany, vol. 95, no. 7, pp. 1075-1096, 2005.

[20] C. S. Charron and C. E. Sams, "Glucosinolate content and myrosinase activity in rapid-cycling Brassica oleracea grown in a controlled environment," Journal of the American Society for Horticultural Science, vol. 129, no. 3, pp. 321-330, 2004.

[21] E. A. S. Rosa and A. S. Rodrigues, "Total and individual glucosinolate content in 11 broccoli cultivars grown in early and late seasons," HortScience, vol. 36, no. 1, pp. 56-59, 2001.

[22] M. E. Cartea and P. Velasco, "Glucosinolates in Brassica foods: bioavailability in food and significance for human health," Phytochemistry Reviews, vol. 7, no. 2, pp. 213-229, 2008.

[23] C. López-Berenguer, M. C. Martínez-Ballesta, C. GarcíaViguera, and M. Carvajal, "Leaf water balance mediated by aquaporins under salt stress and associated glucosinolate synthesis in broccoli," Plant Science, vol. 174, no. 3, pp. 321328, 2008.

[24] C. López-Berenguer, M. D. C. Martínez-Ballesta, D. A. Moreno, M. Carvajal, and C. García-Viguera, "Growing hardier crops for better health: salinity tolerance and the nutritional value of broccoli," Journal of Agricultural and Food Chemistry, vol. 57, no. 2, pp. 572-578, 2009.

[25] D. A. Moreno, M. Carvajal, C. López-Berenguer, and C. García-Viguera, "Chemical and biological characterisation of nutraceutical compounds of broccoli," Journal of Pharmaceutical and Biomedical Analysis, vol. 41, no. 5, pp. 1508-1522, 2006.

[26] M. W. Farnham, P. E. Wilson, K. K. Stephenson, and J. W. Fahey, "Genetic and environmental effects on glucosinolate content and chemoprotective potency of broccoli," Plant Breeding, vol. 123, no. 1, pp. 60-65, 2004.

[27] S. A. McNaughton and G. C. Marks, "Development of a food composition database for the estimation of dietary inatkes of glucosinolates, the biologically active constituents of cruciferous vegetables," British Journal of Nutrition, vol. 90, no. 3, pp. 687-697, 2003.

[28] C. López-Berenguer, C. García-Viguera, and M. Carvajal, "Are root hydraulic conductivity responses to salinity controlled by aquaporins in broccoli plants?" Plant and Soil, vol. 279, no. 1-2, pp. 13-23, 2006.

[29] M. H. Paul, C. Planchton, and R. Ecochard, "Etude des relations entre le développement foliaire, le cycle de développement et la productivité chez le soja," Annales d'Amélioration des Plantes, vol. 29, pp. 479-492, 1979.

[30] F. A. Loewus, "Improvement in anthrone method for determination of carbohydrates," Analytical Chemistry, vol. 24, no. 1, p. 219, 1952.

[31] L. S. Bates, R. P. Waldren, and I. D. Teare, "Rapid determination of free proline for water-stress studies," Plant and Soil, vol. 39, no. 1, pp. 205-207, 1973.

[32] P. S. Nobel, Physicochemical and Environmental Plant Physiology, Academic Press, San Diego, Calif, USA, 1991.
[33] R. Domínguez-Perles, M. C. Martínez-Ballesta, M. Carvajal, C. García-Viguera, and D. A. Moreno, "Broccoli-derived by-products-a promising source of bioactive ingredients," Journal of Food Science, vol. 75, no. 4, pp. C383-C392, 2010.

[34] S. H. Shah, J. Gorham, B. P. Forster, and R. G. Wyn Jones, "Salt tolerance in the Triticeae: the contribution of the D genome to cation selectivity in hexaploid wheat," Journal of Experimental Botany, vol. 38, pp. 254-269, 1987.

[35] H. M. Rawson and R. Munns, "Leaf expansion in Sunflower as influenced by salinity and short-term changes in carbon fixation," Plant, Cell and Environment, vol. 7, pp. 207-213, 1984.

[36] R. S. Purty, G. Kumar, S. L. Singla-Pareek, and A. Pareek, "Towards salinity tolerance in Brassica: an overview," Physiology and Molecular Biology of Plants, vol. 14, no. 1-2, pp. 39-49, 2008.

[37] A. Levigneron, F. Lopez, G. Vasuyt, P. Berthomieu, P. Fourcroy, and F. Casse Delbart, "Plants toward salt stress," Cahiers Agricultures, vol. 4, pp. 263-273, 1995.

[38] P. A. Essah, R. Davenport, and M. Tester, "Sodium influx and accumulation in arabidopsis," Plant Physiology, vol. 133, no. 1, pp. 307-318, 2003.

[39] D. Bartels and R. Sunkar, "Drought and salt tolerance in plants," Critical Reviews in Plant Sciences, vol. 24, no. 1, pp. 23-58, 2005.

[40] M. Black and H. W. Pritchard, Desiccation and Survival in Plants: Drying without Dying, CABI, Wallingford, UK, 2002.

[41] M. M. F. Mansour, "Protection of plasma membrane of onion epidermal cells by glycinebetaine and proline against $\mathrm{NaCl}$ stress," Plant Physiology and Biochemistry, vol. 36, no. 10, pp. 767-772, 1998.

[42] N. Verbruggen, X. J. Hua, M. May, and M. van Montagu, "Environmental and developmental signals modulate proline homeostasis: evidence for a negative transcriptional regulator," Proceedings of the National Academy of Sciences of the United States of America, vol. 93, no. 16, pp. 8787-8791, 1996.

[43] Z. Peng, Q. Lu, and D. P. S. Verma, "Reciprocal regulation of $\Delta$ 1-pyrroline-5-carboxylate synthetase and proline dehydrogenase genes controls proline levels during and after osmotic stress in plants," Molecular and General Genetics, vol. 253, no. 3, pp. 334-341, 1996.

[44] Z. Hong, K. Lakkineni, Z. Zhang, and D. P. S. Verma, "Removal of feedback inhibition of $\Delta 1$-pyrroline-5carboxylate synthetase results in increased proline accumulation and protection of plants from osmotic stress," Plant Physiology, vol. 122, no. 4, pp. 1129-1136, 2000.

[45] J. K. Zhu, "Cell signaling under salt, water and cold stresses," Current Opinion in Plant Biology, vol. 4, no. 5, pp. 401-406, 2001.

[46] M. Carvajal, A. Cerdá, and V. Martínez, "Does calcium ameliorate the negative effect of $\mathrm{NaCl}$ on melon root water transport by regulating aquaporin activity?" New Phytologist, vol. 145, no. 3, pp. 439-447, 2000.

[47] M. C. Martínez-Ballesta, V. Martínez, and M. Carvajal, "Osmotic adjustment, water relations and gas exchange in pepper plants grown under $\mathrm{NaCl}$ or $\mathrm{KCl}$," Environmental and Experimental Botany, vol. 52, no. 2, pp. 161-174, 2004.

[48] D. Evlagon, Y. Ravina, and P. M. Neumann, "Interactive effects of salinity and calcium on hydraulic conductivity, osmotic adjustment and growth in primary roots of maize seedlings," Israel Journal of Botany, vol. 39, pp. 239-247, 1990.

[49] H. Azaizeh and E. Steudle, "Effects of salinity on water transport of excised maize (Zea mays L.) roots," Plant Physiology, vol. 97, no. 3, pp. 1136-1145, 1991. 
[50] B. Muries, M. Faize, M. Carvajal, and M. D. C. MartínezBallesta, "Identification and differential induction of the expression of aquaporins by salinity in broccoli plants," Molecular BioSystems, vol. 7, no. 4, pp. 1322-1335, 2011.

[51] S. Suga, S. Imagawa, and M. Maeshima, "Specificity of the accumulation of mRNAs and proteins of the plasma membrane and tonoplast aquaporins in radish organs," Planta, vol. 212, no. 2, pp. 294-304, 2001.

[52] P. Rodriguez, J. Dell'amico, D. Morales, M. J. Sánchez Blanco, and J. J. Alarcón, "Effects of salinity on growth, shoot water relations and root hydraulic conductivity in tomato plants," Journal of Agricultural Science, vol. 128, no. 4, pp. 439-444, 1997.

[53] S. R. Grattan and C. M. Grieve, "Salinity-mineral nutrient relations in horticultural crops," Scientia Horticulturae, vol. 78, no. 1-4, pp. 127-157, 1998.

[54] M. D. C. Martínez-Ballesta, C. Silva, C. López-Berenguer, F. J. Cabañero, and M. Carvajal, "Plant aquaporins: new perspectives on water and nutrient uptake in saline environment," Plant Biology, vol. 8, no. 5, pp. 535-546, 2006.

[55] A. K. Parida and A. B. Das, "Effects of $\mathrm{NaCl}$ stress on nitrogen and phosphorous metabolism in a true mangrove Bruguiera parviflora grown under hydroponic culture," Journal of Plant Physiology, vol. 161, no. 8, pp. 921-928, 2004.

[56] G. K. Abd-El Baki, F. Siefritz, H. M. Man, H. Weiner, R. Kaldenhoff, and W. M. Kaiser, "Nitrate reductase in Zea mays L. under salinity," Plant, Cell and Environment, vol. 23, no. 5, pp. 515-521, 2000.

[57] X. Yan and S. Chen, "Regulation of plant glucosinolate metabolism," Planta, vol. 226, no. 6, pp. 1343-1352, 2007.

[58] G. Engelen-Eigles, G. Holden, J. D. Cohen, and G. Gardner, "The effect of temperature, photoperiod, and light quality on gluconasturtiin concentration in watercress (Nasturtium officinale R. Br.)," Journal of Agricultural and Food Chemistry, vol. 54, no. 2, pp. 328-334, 2006.

[59] P. Velasco, M. E. Cartea, C. González, M. Vilar, and A. Ordás, "Factors affecting the glucosinolate content of kale (Brassica oleracea acephala group)," Journal of Agricultural and Food Chemistry, vol. 55, no. 3, pp. 955-962, 2007.

[60] R. Tolrà, P. Pongrac, C. Poschenrieder, K. Vogel-Mikuš, M. Regvar, and J. Barceló, "Distinctive effects of cadmium on glucosinolate profiles in Cd hyperaccumulator Thlaspi praecox and non-hyperaccumulator Thlaspi arvense," Plant and Soil, vol. 288, no. 1-2, pp. 333-341, 2006.

[61] H. Keling and Z. Zhujun, "Effects of different concentrations of sodium chloride on plant growth and glucosinolate content and composition in pakchoi," African Journal of Biotechnology, vol. 9, no. 28, pp. 4428-4433, 2010.

[62] J. Beekweelder, W. van Leeuwen, N. M. van Dam et al., "The impact of the absence of aliphatic glucosinolates on insect herbivory in Arabidopsis," PLOS ONE, vol. 3, no. 4, Article ID e2068, 2008.

[63] J. W. Fahey, A. T. Zalcmann, and P. Talalay, "The chemical diversity and distribution of glucosinolates and isothiocyanates among plants," Phytochemistry, vol. 56, no. 1, pp. 5$51,2001$.

[64] E. T. Scheuner, A. Krumbein, I. Schonhof, and M. Schreiner, "Increasing the alkyl glucosinolate level in Broccoli by leafstalk infusion of methionine," Journal of Applied Botany and Food Quality, vol. 79, no. 3, pp. 175-178, 2005.

[65] A. Wahid and A. Ghazanfar, "Possible involvement of some secondary metabolites in salt tolerance of sugarcane," Journal of Plant Physiology, vol. 163, no. 7, pp. 723-730, 2006. 

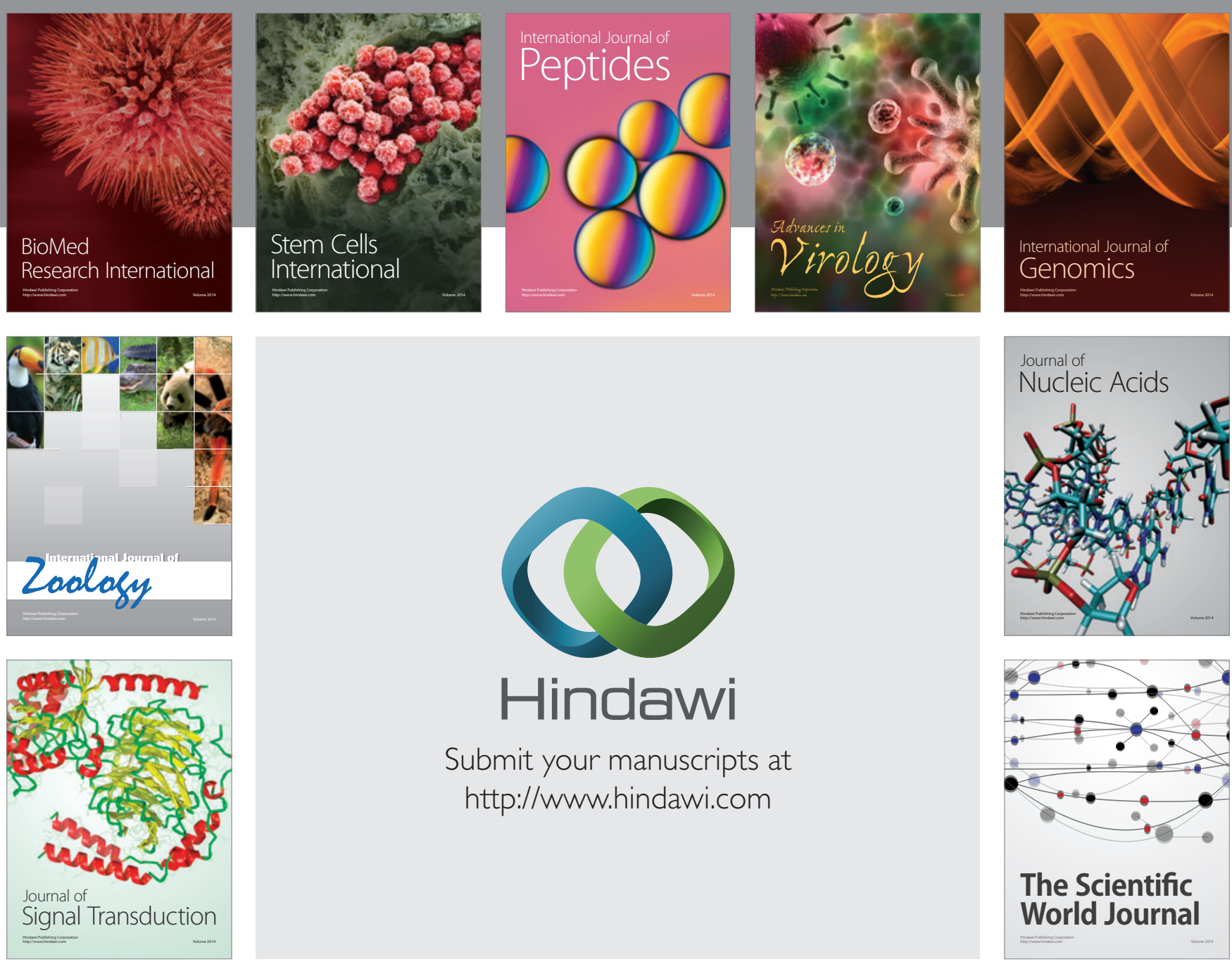

Submit your manuscripts at

http://www.hindawi.com
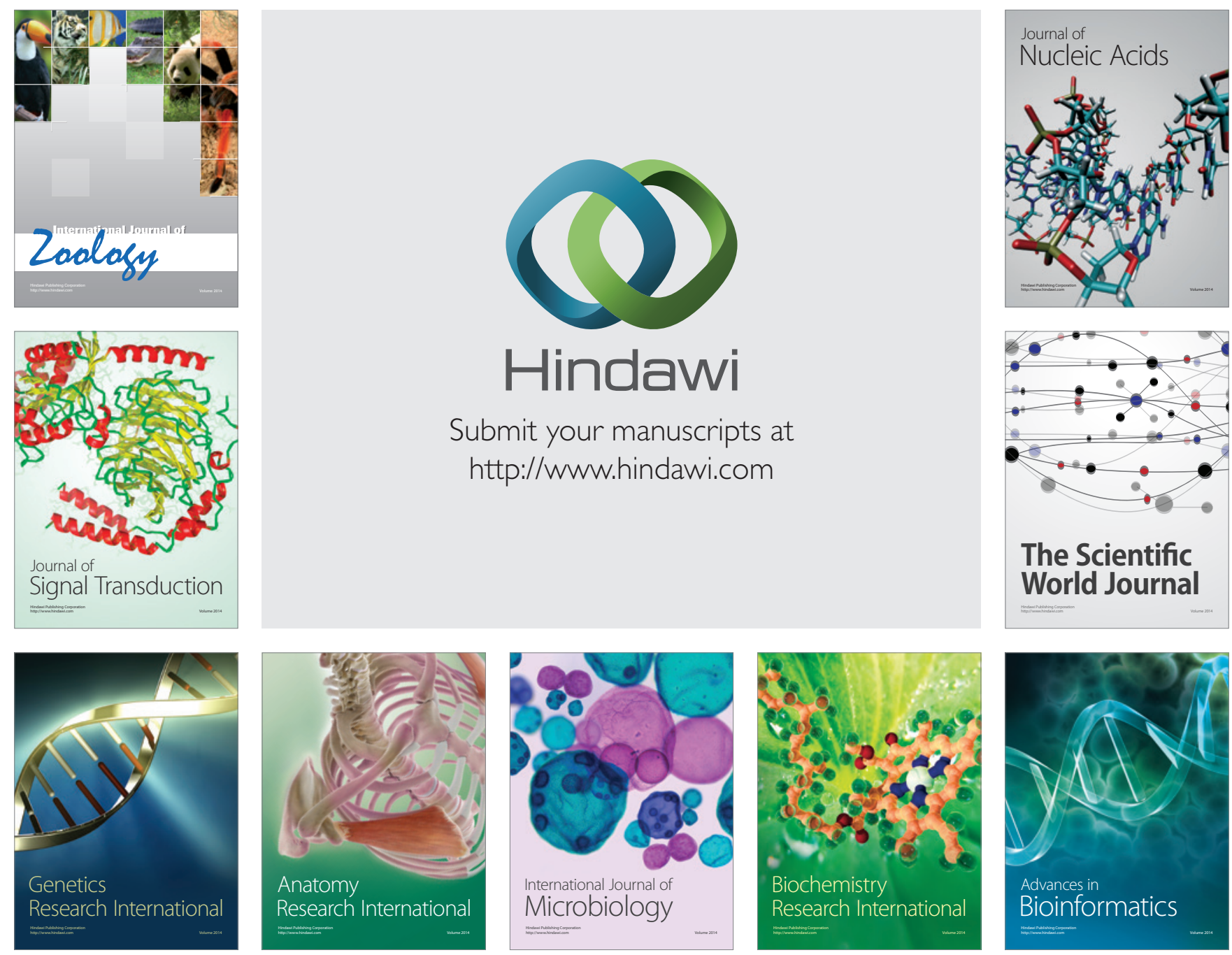

The Scientific World Journal
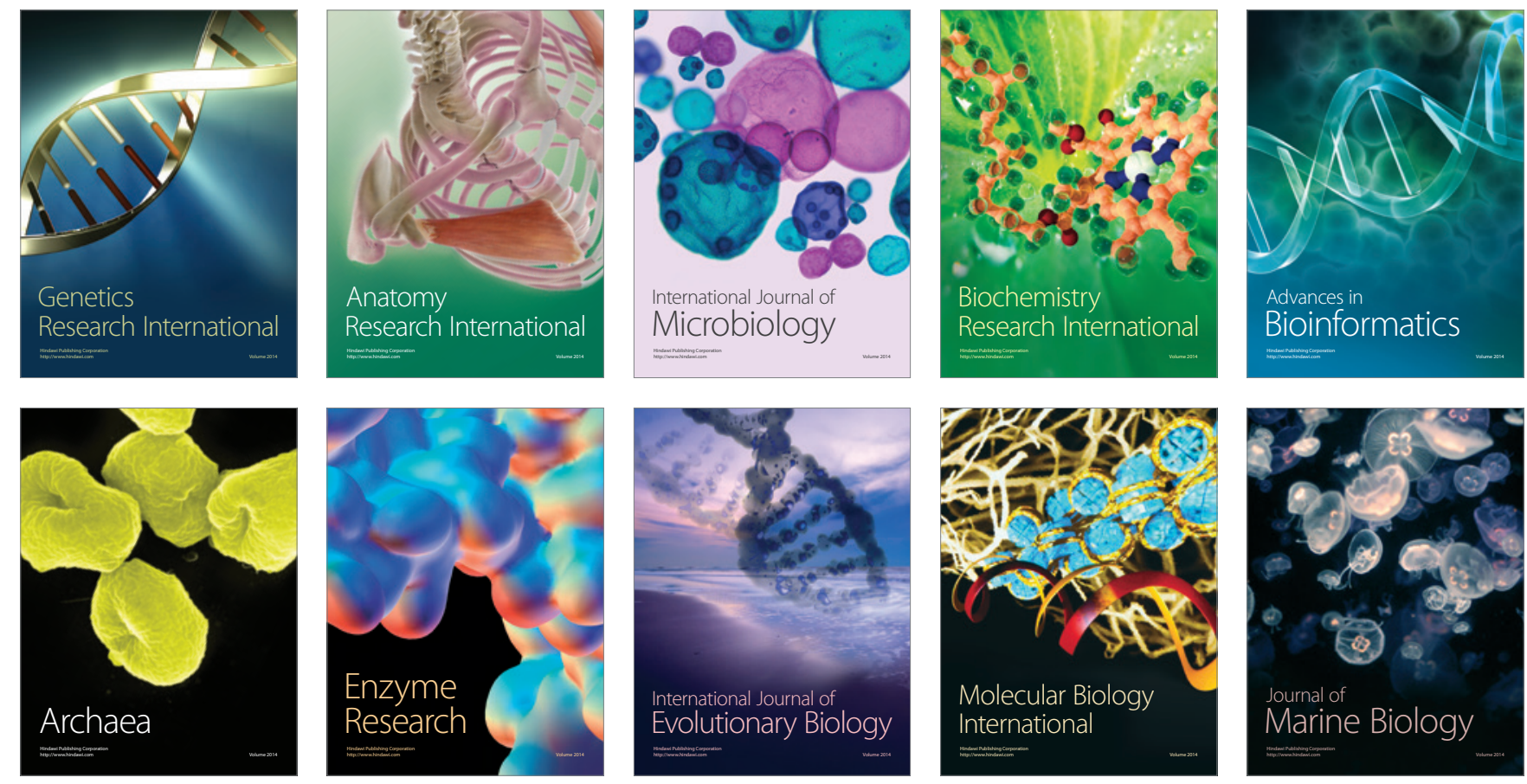